\title{
Contemporary Role of SMEs in Employment in Manufacturing and Service Industries
}

\author{
Inese Mavlutova ${ }^{1}{ }$ Kristaps Lesinskis $^{2}$, Grigorijs Olevskis ${ }^{3}$ \\ ${ }^{1}$ Department of Finance, BA School of Business and Finance, Riga, Latvia \\ ${ }^{2}$ Department of Entrepreneurship and Business Informatics, BA School of Business and Finance, Riga, Latvia \\ ${ }^{3}$ University of Latvia, Faculty of Business, Management and Economics, Riga, Latvia \\ E-mails: 'inese.mavlutova@ba.lv; ${ }^{2}$ kristaps.lesinskis@ba.lv (corresponding author); ${ }^{3}$ grigol@lanet.lv
}

Received 14 February 2017; accepted 05 April 2017

\begin{abstract}
Analysis made in the article allows to conclude that the SME sector of high-tech manufacturing industries plays growing role in solving the problems of employment in developed countries. However, the major problem is that it is capable for only partial compensation of the loss of jobs in labour intensive sectors of the economy. Accumulation of knowledge of the population in industrialized countries together with high levels of computer literacy contributes to the revitalization of business services sellers that are mainly small sized businesses. In the era of fast growing technology industries, in particular related to IT sector, the role of SMEs in economy is increasing as they are main players in start -up communities and IT industries in general. Thus they can growingly contribute to the employment and labour market. The authors proceed from the assumption that service sector, and business services in particular, to a certain extent are capable of absorbing of workforce. This article argues that employment in the service sector in the developed economies is still largely focused on traditional sectors of activity. The purpose of the paper is to investigate latest trends of SMEs role in employment in the developed countries and the role of service sector in stabilizing labour market. Theoretical approaches, statistical data and policy analysis are used to research contemporary labour market trends. Knowledge intensive services that are important from the point of view of economic dynamics, only start to concur positions in the developed countries.
\end{abstract}

Keywords: employment, manufacturing, knowledge-intensive business services; small and medium enterprises, competitiveness, productivity.

JEL Classification: E24, L60, J24, M10.

Conference topic: Contemporary Issues of Economics and Management Studies: Problems and Perspectives.

\section{Introduction}

Employment is considered to be one of the most important economic indicators when analysing the country's economic prospects. Ageing of population, deteriorating birth rates and growing mortality rates are common in most parts of the European Union. Recently another wave of immigration from developing countries of Western Asia and North Africa has occurred and will continue. In result, European Union is facing labour deficit and structural problems in labour market in coming years. Significance of the research is related also to the structural problems in European labour markets as despite the labour deficit in several European countries rather high unemployment rates can be observed. It is hard to underestimate the role of SMEs sector in solving employment problems as it provides the largest share of jobs in a private sector economy.

In 2010, the European Union approved document called "Europe 2020" which was the EU's growth strategy for the coming decade. The strategy contains five targets, one of them being employment, and aims at 75\% of the 20-64 yearolds to be employed by 2020. Striving for inclusive growth the strategy contains flagship initiative "An Agenda for New Skills and Jobs" that calls for modernizing labour markets by facilitating labour mobility and the development of skills throughout the lifecycle with a view to increasing labour participation and better matching labour supply and demand.

Balance between labour supply and demand on labour market is achieved not only through employers and employees' consensus, but also through thorough sustainable employment policy developed by government and SMEs development.

(C) 2017 I. Mavlutova, K. Lesinskis, G. Olevskis. Published by VGTU Press. This is an open-access article distributed under the terms of the Creative Commons Attribution (CC BY 4.0) License, which permits unrestricted use, distribution, and reproduction in any medium, provided the original author and source are credited. 
The objevtive of the paper is to investigate the latest global employment trends and SMEs sector contribution to labour market development in manufacturing and service industries in particular.

The methodological framework of the research is built on general labour economics theoretical approaches followed by testing statistical data and policies applied. Qualitative methods are used for theoretical overview and analysis of labour economy and employment. Policy document analysis and personal observations of the authors are used to reveal the problems in the current labour market and employment situation in the EU. Quantitative research methods: statistical data analysis, forecasting and other financial calculations are used to analyse trends and structural problems in labour markets. Authors provide several recommendations on possible incentives to stabilize and develop labour markets in the European Union.

\section{Theoretical aspects of employment for manufacturing and service industries}

The complex of relationships, most adequately characterizing the principles, the content and form of participation of the working population in production, in science is identified with employment as the economic category. Economic dimension of employment is mainly the labour market.

Encyclopaedia Britannica defines: "Labour economics, study of the labour force as an element in the process of production. The labour force comprises all those who work for gain, whether as employees, employers, or as selfemployed, and it includes the unemployed who are seeking work" (Encyclopaedia Britannica 2016). Labour economics includes the factors affecting the efficiency of the workers, their deployment between different industries and occupations, modern labour economics especially deals with the labour force of contemporary industrialized economies.

Theory of economics emphasizes the importance of labour productivity as one of the core indicators of efficiency of labour market and economy in general. In the European Union labour productivity per hour worked is calculated as real output (deflated GDP measured in chain-linked volumes, reference year 2010) per unit of labour input (measured by the total number of hours worked). Measuring labour productivity per hour worked provides a better picture of productivity developments in the economy than labour productivity per person employed, as it eliminates differences in the full time/part time composition of the workforce across countries and years (Eurostat 2016). Labour productivity depends on such factors as investment and saving in physical capital, new technologies and human capital.

Demography, urbanization, globalization, technology, and macroeconomic crises bring, as the World Bank experts believe, about formidable jobs challenges. Countries that fail to address them may fall into vicious circles of slow growth in labour earnings and job-related dissatisfaction affecting a sizable portion of the labour force. Youth unemployment and idleness may be high, and women may have fewer job opportunities, leaving potential economic and social gains untapped. A repeating pattern of small gains in living standards, slow productivity growth, and eroding social cohesion can set in. In contrast, countries that address these jobs challenges can develop virtuous circles. The results - prosperous populations, a growing middle class, increased productivity, and improved opportunities for women and youth - may then be self-reinforcing in particular with strong contribution from SME sector (World Bank 2013).

Employment is the result of equilibrium determined by labour market: working-age population that has been able to carry out activities that can generate income in the form of wages or profits (Mavlutova et al. 2016). Sloman and Hinde (2007) refer to Keynesian theory in which it is assumed that there is a maximum level of GDP that can be obtained at any one time, and if equilibrium GDP is at this level, there will be no deficiency of aggregate demand and hence no disequilibrium unemployment. Employment is one of the most important factors of economic growth (traditional, approved by the practice of management in the period of domination of automatic production and occupying its rightful place in all economic growth models). Therefore, the risk of slowdown in productivity as a consequence of the unsolved problems of employment is taken as a threat signal of economic slowdown. To reduce the risk of slowdown, it is necessary to improve the use of available labour force and to accelerate structural reforms in the economy and to increase the role of SMEs.

Employment is multifaceted socio-economic phenomenon having a content, form, structure, and organization. Therefore authors of the article limit their research of employment to the framework of normative perception about employees and employers:

- Employees, who get a basic remuneration not directly dependent the revenue of the employer.

-Employers, who hold self-employment jobs (i.e. whose remuneration depends directly on the (expectation of) profits derived from the goods and services produced) and engage one or more person to work for them as 'employees', on a continuous basis (International Labour Organization 1993).

It is interesting to note in this regard that a characteristic feature of modern understanding of employment is the uncertainty of status of employee and employer. In other words, person may be an employer and employee at the same time or may regularly switch from the status of self-employed to employee and vice versa. And there is a myriad of options how a person may simultaneously represent himself in status of employer and employee. The choice of status in this case is largely determined by the level of motivation of individual who must decide on its own employment dilemma:

- Guided by information about supply and demand in the labour market and based on its own view on the prospects of functioning of given industry - to choose the employee status, especially in SMEs sector.

- Assessing its own intellectual capital, social networks, financial possibilities, level of the market competition, business risks etc. - to try out his own small business. 
By signing a contract of employment with an employer, individual expresses his readiness to work for a certain material rewards that depend on the results of his work.

The literature presents quite a number of approaches to the justification of the reasons for qualitative changes in employment. Thus, Manuel Castells (2009), considering the economic development of industrialized countries, has formulated factors determining the nature and dynamics of employment evolution. From the standpoint of the subject of this research the most interesting are the following trends (Castells 2007):

- the phasing out of agricultural employment;

- the steady decline of traditional manufacturing employment;

- the rise of both producer services and social services, with the emphasis on business services in the first category, and health services in the second group;

- the increasing diversification of service activities as sources of jobs;

- the rapid rise of managerial, professional, and technical jobs;

- the formation of a "white-collar" proletariat, made up of clerical and sales workers;

- the relative stability of a substantial share of employment in retail trade;

- the simultaneous increase of the upper and lower levels of the occupational structure;

- the relative upgrading of the occupational structure over time, with an increasing share of those occupations that require higher skills and advanced education proportionally higher than the increase of the lower-level categories.

The authors agree with trends mentioned above and would like to underline the role of SMEs in described processes Labour economics covers a range of issues related to market of wage labour and that are fundamental to understand how world of work is connected to wage formation, employment and economic growth, the importance of demographic issues, human capital, and labour market regulations. These topics have been described and analysed thoroughly in academic literature, providing for extensive debates on number of issues, including the impact of labour market institutions, such as minimum wages and employment protection legislation, trade unions and employers' organizations (International Labour Office 2013).

Rowthorn and Coutts summarize five explanations of deindustrialization that have been advanced in the literature. The first of these is specialization, referring to the domestic outsourcing of activities previously performed in house in manufacturing to specialized service providers, resulting in an apparent decline in manufacturing employment that is a 'statistical artefact' rather than real. Second, a fall in the relative prices of manufactures means that they account for a smaller share of consumer expenditure. Third, the higher rate of productivity growth in manufacturing relative to services is associated with slower employment growth in manufacturing than in services. Fourth, international trade might negatively affect manufacturing employment in advanced economies by increasing productivity through higher competitive pressures, eliminating low-value added activities or inefficient firms, and by replacing relatively labour-intensive activities subject to import pressures with less labour-intensive activities producing sophisticated exports. Finally, decreases in the rate of investment will tend to decrease the share of manufacturing (in both employment and GDP), since a disproportionately large share of investment expenditure is accounted for by manufactures (Rowthorn, Coutts 2004).

The decline in manufacturing employment in the industrialized world is not a new phenomenon and there are a raft of potential explanations ranging from productivity to globalization. So Rowthorn and Ramaswamy argue that deindustrialization is explained by developments that are internal to an advanced economy stimulated primarily by faster growth in manufacturing productivity which, in turn, leads to relative price changes and shifts in the structure of the economy. An alternate hypothesis is that the manufacturing employment decline is primarily due to globalization and the rise of manufacturing in developing economies. Several recent contributions relate the decline of manufacturing employment to episodes of globalization and in particular the rise of China in the global economy (Rowthorn, Ramaswamy 1999). Pierce and Schott document the "swift decline" of US manufacturing after China's entry into WTO and link the decline to changes in US trade policy that eliminated the threat of tariff hikes (Pierce, Schott 2012).

In 1967, Baumol identified the key theoretical foundation for the expansion of service sector employment - the slower productivity growth in services compared to manufacturing. According to what became later known as "Baumol's disease", the expansion of the employment share in services relative to industry is the direct consequence of services' lower productivity performance (Baumol, 2001).

Accumulated volume and quality of knowledge by population of industrialized countries coupled with the relatively high level of computer literacy has contributed to the revitalization of the business services vendors. Internet technologies have pushed the boundaries of business making it attractive to almost every educated person in SMEs sector. The result is that economists and lawyers, engineers and programmers have rushed into providing services. SMEs today not only demonstrate the strong sales growth, but also the ability to create and use innovations. That is why the giving rationale to providing favourable conditions to fast growing SMEs based on sales of services has become an actual problem of modern economic science. 


\section{Manufacturing and service industries effect on employment}

In the last 15 years EU, United States and Japan smoothly progressed towards economies with an increasing weight in the services sectors and a corresponding decrease in the manufacturing sectors. This slow trend is visible when one compares the changes in the shares of the EU's employment in manufacturing and services in 1995 (respectively $20.1 \%$ and $62.9 \%$ ) and in 2009 (respectively $15.7 \%$ and $70.4 \%$ ). The Japanese economic structure shows very similar figures and progress over the 1995-2007 period (2007 being the last year available), with the employment share of the manufacturing sector dropping from $20.8 \%$ to $17.4 \%$ while the share of employment in the services sector increased from $60.7 \%$ to $68.2 \%$. In 1995, the economic structure of the United States showed a larger share of employment in the services sector. This fact lies in the correspondence between the bigger weights of the ICT services sectors compared to the EU. Back in 1995, the manufacturing sector in the United States had a share of employment of $13.6 \%$ and the services sector a share of $78.2 \%$. Twelve years later, manufacturing is accounting for less than $10 \%$ of total employment and services have passed $81.6 \%$. In the period $1995-2009$, the EU average annual growth rate of employment in the manufacturing sector was $-1.7 \%$, compared to $-1.5 \%$ in Japan and $-2.7 \%$ in the United States. In the service sector, the average annual growth rate between 1995 and 2009 was $0.8 \%, 1 \%$ in Japan and $0.4 \%$ in the United States. This implies a gradual trend towards a service economy, with a decrease in manufacturing sector (European Commission 2011).

Modern industrial entrepreneurs are not active players in the labour market. The main reason for that is significant decrease in prevalence of textile, clothing and footwear producing enterprises in industrialized countries. Moving labour intensive industrial production to Southeast Asia has strengthened the position of shadow economy built on informal employment, i.e. on the use of statistically unregistered labour that is not subject to taxation. The total number of employees on manufacturing enterprises, according to United Nations Industrial Development Organization (United Nations Industrial Development Organization 2013), accounted for 388 million persons worldwide in 2009, of which 200.3 million officially registered.

Now more than ever, Europe needs industry and industry needs Europe. The Single Market, with 500 million consumers, 220 million workers and 20 million entrepreneurs, is a key instrument in achieving a competitive industrial Europe. One out of four jobs in the private sector in the European Union is in manufacturing industry, and at least another one out of four is in associated services that depend on industry as a supplier or as a client. $80 \%$ of all private sector research and development efforts are undertaken in industry - it is a driver of innovation and a provider of solutions to the challenges our societies are confronted with. European industry had successfully maintained its share of world trade over the last decade in the face of stiff pressure from new competitors. Manufacturing itself accounts for $75 \%$ of exports. Sectors such as pharmaceuticals and engineering developed strongly. The motor, chemicals, and aerospace industries were also expanding (European Commission 2010).

Formal and informal components of labour demand and supply create difficulties to assess the actual size of employment in the manufacturing industry. Due to this it is reasonable to carry out analysis of the dynamics and structure of the employment in the manufacturing industry based on sufficiently reliable statistical information on informal employment. Thus, number of people employed in the manufacturing industry in the world has increased by $43.4 \%$ in 2010 compared to 1970 (see Table 1).

Table 1. Structure and dynamics of formal employment in the world manufacturing industry, as a percentage (Source: United Nations Industrial Development Organization 2013)

\begin{tabular}{|c|c|c|c|c|c|}
\hline \multirow{2}{*}{$\begin{array}{c}\text { Ranking, } \\
2010\end{array}$} & \multirow{2}{*}{ Country } & \multicolumn{3}{|c|}{ The share of employment in the world } & \multirow{2}{*}{$\begin{array}{l}\text { Growth rate } \\
\frac{2010}{1970}\end{array}$} \\
\hline & & 1970 & 1990 & 2010 & \\
\hline 1 & China & 10.13 & 23.53 & 34.34 & 484.5 \\
\hline 2 & United States & 13.03 & 9.71 & 6.36 & 69.8 \\
\hline 3 & India & 3.40 & 3.98 & 5.88 & 251.1 \\
\hline 4 & Russia (USSR) & 19.41 & 16.83 & 3.90 & $\ldots .$. \\
\hline 5 & Brazil & 1.48 & 2.32 & 3.84 & 366.7 \\
\hline 6 & Japan & 7.79 & 6.2 & 3.63 & 67.0 \\
\hline 7 & Germany (FRG) & 5.87 & 3.95 & 3.10 & $\ldots .$. \\
\hline 8 & Bangladesh & 0.15 & 0.57 & 2.53 & 2550.0 \\
\hline 9 & Viet Nam & 0.03 & 0.12 & 2.20 & $\ldots .$. \\
\hline 10 & Indonesia & 0.35 & 1.47 & 2.11 & 840.0 \\
\hline \multicolumn{2}{|c|}{ number of employees in the world (millions of people) } & 139.7 & 180.3 & 200.3 & 143.4 \\
\hline
\end{tabular}


Table 1 clearly reflects the nature of globalization processes since 1970-ies with a significantly increasing role of developing economies in the global markets. It has been related also to the movemement of production from developed to developing world.

The resulting vector of formal employment dynamics in the global manufacturing industry for the period 1970 2010 was formed on the basis of two divergent trends - the growth and decline:

- more than a three-fold increase occurred in Southeast Asia, the Pacific, South Asia, Latin America and the Caribbean

- decline occurred in the industrialized countries of Europe - by $77.5 \%$, and in North America - by $70 \%$ (United Nations Industrial Development Organization 2013).

Top rated in 2010 became "world factory" - China: $34.34 \%$ of all employees in the global manufacturing industry were inhabitants of China. However, it is interesting to note the fact that US became second in that rating. This happened despite the fact that from 1970 till 2010 the employment in the US manufacturing industry decreased by $30.2 \%$. The only representative of Europe in the top ten in 2010 was Germany, occupying the $7^{\text {th }}$ position. The manufacturers of Germany, whose economy is considered to be the "locomotive" of EU, make a worthy contribution to the economic growth of the country. In 2012, the share of processing industry was $22.4 \%$ of gross domestic product in Germany. For comparison, the value of this indicator on the average in EU-27 was 15.2\%, in Finland 10\%, United Kingdom 10.3\%, Italy $15.6 \%$ (European Commission 2014).

Therefore, it can be argued that Germany's way of overcoming from the engine to the high-tech manufacturing is fairly painless. The successes of German manufacturers are predetermined:

- firstly, because of the fact that the leading subsectors of the manufacturing industry in Germany is dominated by multinational corporations (Siemens AG, Volkswagen, BASF AG, Deutsche Telekom AG, Leica Microsystems). Huge investment by corporations in the development and implementation of innovation is an effective tool for the formation of high-tech manufacturing.

- secondly, because of the officials forming the industrial policy on the federal and state levels, and actively lobbying the interests of German manufacturers in governing institutions of the EU.

Experts have formulated the most important preconditions to ensure a competitive advantage of German manufacturers:

1) successful operation of small and medium-sized enterprises in Germany, which provide jobs for about $70 \%$ of the workforce of the country and produce complicated, difficult to imitate production;

2) highly skilled workforce;

3) high quality infrastructure.

Experts have concluded that Germany has concentrated its efforts on the development of new technologies and innovative capabilities (Deloitte 2013).

The ability of entrepreneurs of US, Germany, Italy ( $11^{\text {th }}$ position in rating of 2010$)$, France ( $14^{\text {th }}$ position), United Kingdom $\left(16^{\text {th }}\right.$ position) to maintain the competitiveness of the national manufacturing industry may be proof to the fact that these countries possess strong enough position in high-tech manufacturing and knowledge intensive services ensuring these activities. Authors take into account that Eurostat in the high-tech manufacturing includes manufacturing of pharmaceuticals; manufacturing of computer, electronic and optical products, manufacturing of machinery and equipment; and manufacturing of aircraft. According to statistical information provided by Eurostat, the activity of manufacturing enterprises in Germany is characterized as following for the year 2011:

- the share of high-tech enterprises in the total number of manufacturing enterprises was $4.2 \%$, but the number of working for them $-7.1 \%$ of total employment in the manufacturing industry of Germany;

- on average, one high-tech enterprise in manufacturing sector employed 57 workers, while in the manufacturing industry in Germany as a whole the respective number was 34 workers.

- the largest share in high-tech manufacturing in 2011 belonged to manufacturers of electrical machinery and optical instruments, office machinery and computers $-91.3 \%$ of all enterprises and $62.3 \%$ of employed. It is noteworthy that the workforce in the industry is concentrated mainly in medium and large enterprises $81.7 \%$ (Eurostat 2015b).

Fast growing high-tech enterprises in Germany are able to solve the employment problem in the industry only in some cases, as evidenced by the information in Figure 1.

In 2012, average number of employees in the fast growing company ( 88 people) was 2.6 times higher than in the whole manufacturing industry in Germany in 2011. However, among high-tech companies growth was observed only in manufacturing of electrical machinery and optical instruments, office machinery and computers. Moreover, fastgrowing manufacturers of aircraft companies have been significantly lagging behind in the number of employees compared to enterprises that had the standard rates of growth.

Given information can serve as an argument in support of the conclusions of UNIDO experts that industries that are classified as high-tech, do not play a significant role in solving the employment problems. It can only partially compensate for the loss of jobs in labour intensive manufacturing industries. But they are crucial in the accumulation of capital, development of skills and increase the level of knowledge in the economy, that is, they are crucial in the 
formation of productivity growth conditions. Manufacturing industry in the developed countries keeps the motor function of economic growth, as is the main source of capital, knowledge, and (to some extent) jobs (United Nations Industrial Development Organization 2013).

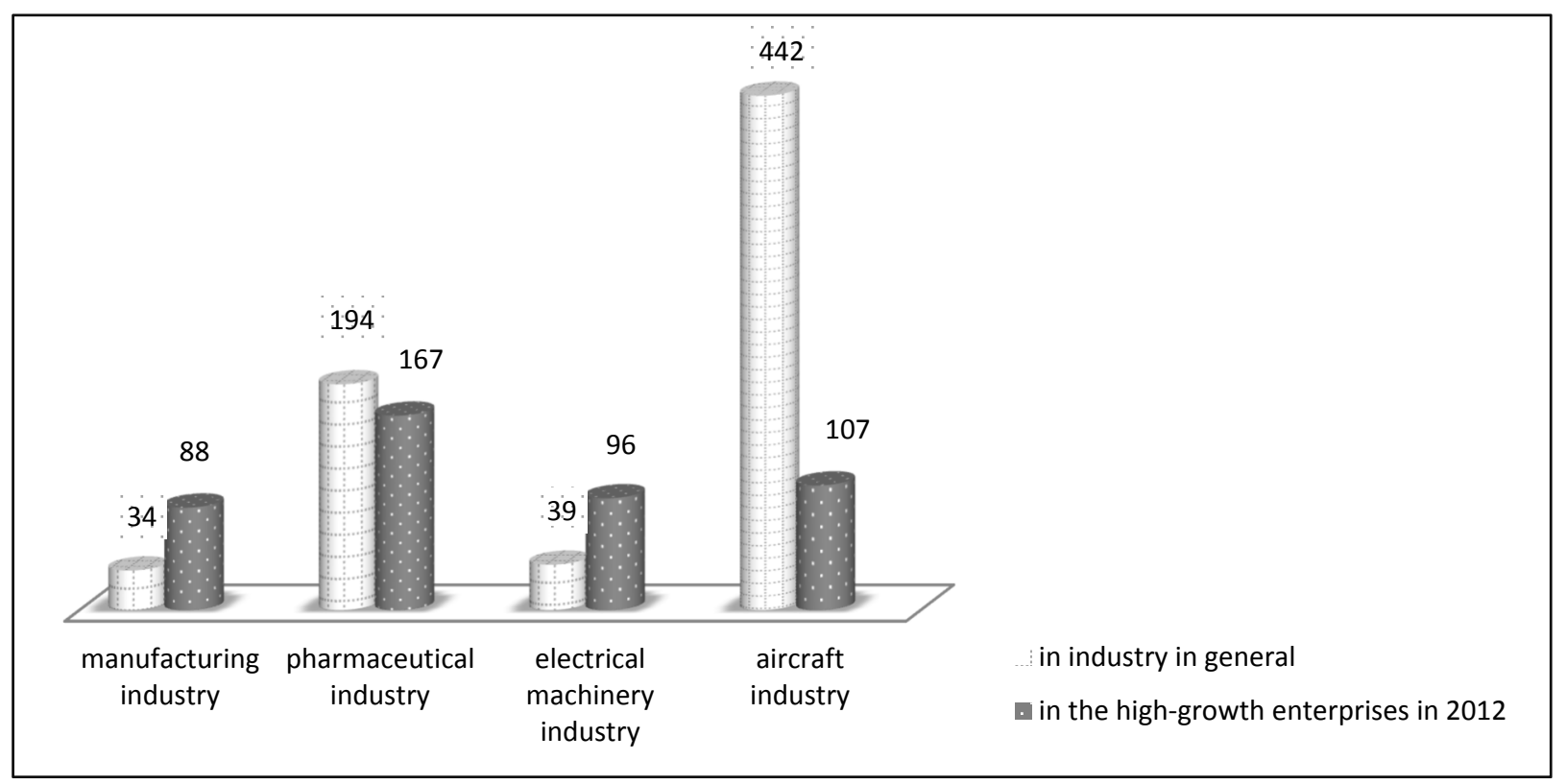

Fig. 1. The average number of employees in one Germany manufacturing enterprise (Source: compiled by the authors using Eurostat 2015a, Eurostat 2015c)

The attractiveness of the service sector in the labour market is confirmed by the employment statistics. According to experts of the International Labour Organization (ILO), $45.1 \%$ of all employees in the world were employed in the service sector in 2013. Moreover, in the past two decades, the proportion of service sector workers in total employment in the world increased by 10.1 percentage points. Overall, slightly below $32 \%$ of the global labour force was employed in agriculture in 2013 - a decline of 11.7 percentage points compared with the previous two decades. Employment in the manufacturing now accounts for about $23 \%$ of global employment at a growth rate of only 1.6 percentage points (International Labour Organization 2014).

In the economies of industrialized countries, the dominance of the service sector in the labour market looks even more impressive. In the US, for example, $80.1 \%$ of all workers in 2011 were employed in the service sector - see Figure 2.

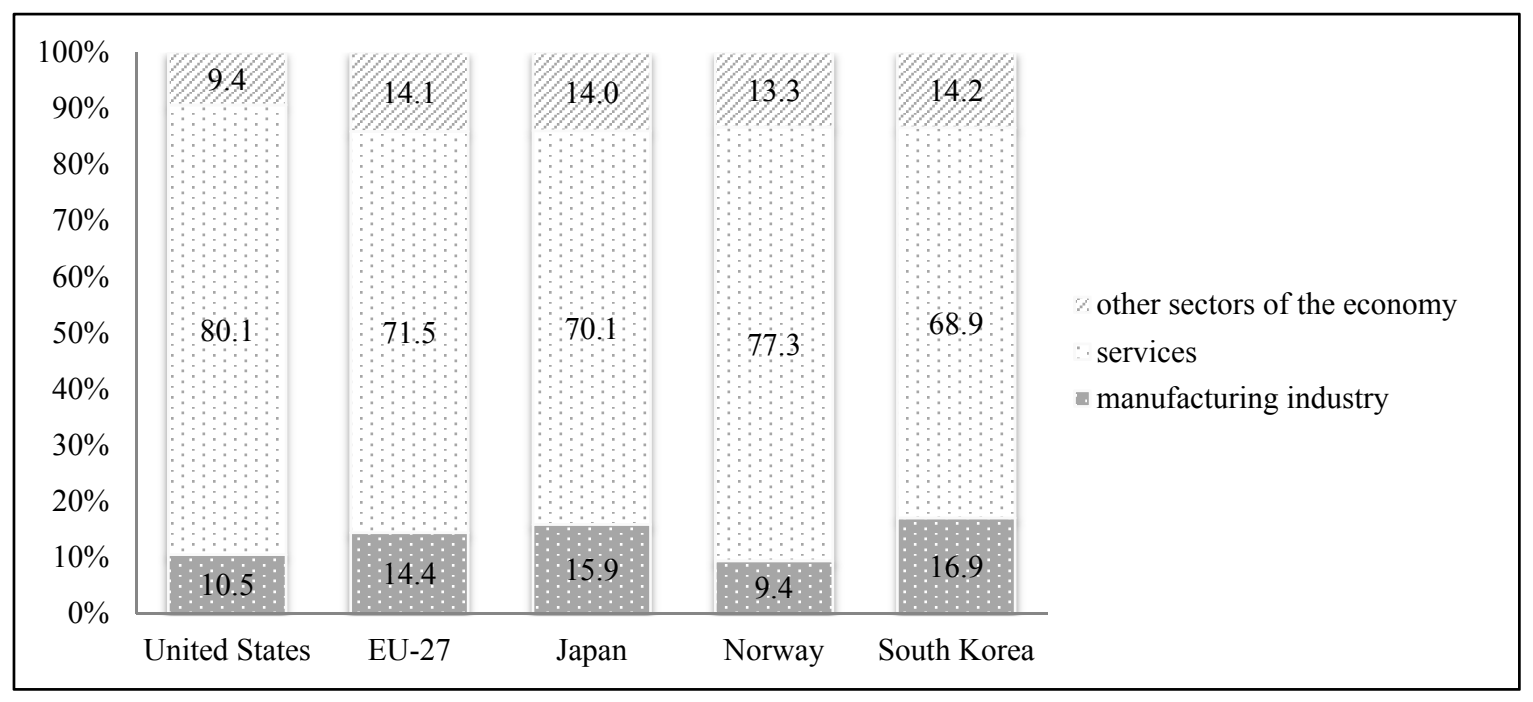

Fig. 2. Employment in the basic sectors of economy in industrialized countries in 2011, as a percentage (Source: European Commission 2013b) 
The data in Figure 2 which reflect the huge role of service sector in employment nowadays is related both to changing structure in the economies of developed countries and to intensity with which manufacturing and services use labour resources.

The service sector is the determining factor in shaping the demand in the labour market in other industrialized countries too. It should be noticed that the share of service sector employment amounted to $71.5 \%$ in the EU-27.

Crucial role in addressing employment problems in service sector is provided by traditional activities - hotel services and public catering, wholesale and retail trade, repair of motor vehicles and motorcycles, real estate activities. In other words, those activities which, according to European Classification of Economic Activities (NACE Rev.2), are not included in knowledge-intensive services (KIS).

The division of the service sector in the traditional and knowledge-intensive is, as rightly noted by Russian researchers, conditional in its character due to unclear criterions for defining the meaning of "knowledge-intensive". In statistics this uncertainty is reflected as the expansion of the boundaries of knowledge-intensive services. Thus, Eurostat includes transport services and education, postal services and health care, science and financial activities (Eurostat 2015e). But statistics, even with such expanded approach, do not indicate that knowledge-intensive services currently play a decisive role in shaping labour supply in EU. Even in Germany, United Kingdom, France, Spain and Italy countries that employed $65.8 \%$ of those employed in service sector in the EU in 2011 , the proportion of workers representing knowledge-intensive services, according to Eurostat classification, did not exceed half of the employed in the economy of EU-27 - see Table 2.

Table 2. Employment in the service sector in 2011, as \% of employment in the economy of the EU-27 (Source: Eurostat 2015d)

\begin{tabular}{l|c|c|c}
\hline & Services generally & $\begin{array}{c}\text { Knowledge-intensive } \\
\text { services }\end{array}$ & $\begin{array}{c}\text { High-technology knowledge-in- } \\
\text { tensive services }\end{array}$ \\
\hline Germany & 70.2 & 40.2 & 2.7 \\
\hline Spain & 74.5 & 35.6 & 2.9 \\
\hline France & 74.7 & 44.5 & 3.0 \\
\hline Italy & 67.8 & 33.8 & 2.3 \\
\hline United Kingdom & 79.6 & 48.5 & 3.4 \\
\hline EU-27 & 65.4 & 36.7 & 3.9 \\
\hline
\end{tabular}

As can be seen in Table 2, in the UK, where the vast majority (79.6\%) of the working population were employed in the service sector, less than a half $(48.5 \%)$ of workers were employed in knowledge-intensive service sector. In the economic areas as information, communications and computer services, as well as scientific research, that is, in those industries that are included in the high-technology knowledge-intensive services, there were occupied only $3.4 \%$ of the UK workers in 2011. In the other leading EU countries, the value of given indicator was even smaller.

The statistical data presented in Table 2 shows that employment in the service sector is still largely focused on traditional areas of activity. Knowledge-intensive services, which are important from the point of view of dynamics of economy, are only starting to conquer positions in the EU single market. One of the reasons for such a slow formation of so important sector for modern industrialized country, which uses skilled labour, is a permissive attitude of politicians, scientists and civil society of EU Member States to the business in the markets of knowledge-intensive services.

Business in the area of knowledge-intensive services is classified by researchers and statisticians as knowledgeintensive business services - KIBS. The OECD includes in the KIBS the following services:

- IT-consulting;

$-\mathrm{R} \& \mathrm{D}$ services;

- legal;

- accounting;

- marketing and advertising;

- business consulting;

- human resource development (OECD 2007).

However, it should be noted that the statisticians of the EU and the US have not reached a consensus on the issue of the structure of knowledge-intensive business services. Therefore, cross-country comparisons of the extent and dynamics of this phenomenon require a certain correction.

The largest share (32\%) of knowledge-intensive business services (market, financial and ICT) belonged to the US in 2012. EU was the second biggest (23\%) provider of knowledge-intensive business services. In recent years, China's share is growing rapidly, reaching $8 \%$ of global volume in 2012, thus equalling Japan (World Bank 2013). In the EU, knowledge-intensive business services contribute $7.6 \%$ to the total volume of production and provide jobs for almost 15 million Europeans. What is more, the sector is dominated by a few multinational corporations, even though 
presence of SMEs is quite large. The contribution of enterprises and entrepreneurs of Germany, the UK, France and Italy is approximately $3 / 4$ of total volume of knowledge-intensive services in the EU (Eurostat 2015e).

\section{SME sector activity and employment analysis}

Looking back to the period since the beginning of financial crisis in 2008, the EU SME sector contributed disproportionally to both the decline in employment from 2008 to 2013 and the subsequent employment recovery in 2014. SMEs accounted for $67 \%$ of total EU28 employment in the EU non-financial business sector in 2014, but from 2008 to 2013 , SME's accounted for $73 \%$ of the 2.2 million drop in employment in the non-financial businesses sector across the EU28, while in 2014, SMEs accounted for $71 \%$ of 1.5 million increase in employment in the same sector. Overall, from 2008 to 2014, SMEs accounted for 76\% of the net decrease in employment. It was only in 2014 that SMEs finally started to outperform large enterprises in terms of employment creation (European Commission 2015).

There are both similarities and differences when SMEs sector of the EU is compared to that of USA and Japan. There is a difference when EU is compared to these countries assessing contribution to value added and employment.

According to data, the EU28 has the largest number of SMEs (more than 22 million) and posts the highest level of SME employment among the three regions. However, the smaller number of SME firms (18.8 million) in the USA generated EUR 3.8 trillion in value added, almost 9\% more than the $18 \%$ larger number of EU28 SMEs. In Japan, the SME sector is much smaller in absolute terms - the country has 3.9 million SMEs and these firms provide 33 million jobs. However, as the three economies vary in size, a more realistic way to compare the relative importance of the SMEs in each of the three economies is to scale the SME figures by GDP and the total nonfinancial business economy. Interestingly, in the case of the number of SMEs, the EU28 and the USA are roughly comparable with 1.65 and 1.5 SMEs per million GDP. In contrast, the importance of SMEs in providing employment is similar in the EU and Japan (6.6 and 7.1 person employed per SME), and much lower in the USA, where SMEs account for slightly more than half $(52 \%)$ of total employment in the non-financial business economy. However, the evolution of SME value added between 2009 and 2012 was much more positive in the USA (24\%), than in the EU (8\%). (European Commission 2015). This allows to conclude that on average the SME sector in USA is more productive and European SMEs are losing their competitiveness internationally.

According to European Commission, the results of a simple cross-country correlation analysis of growth in real GDP and SME employment show that a 1 percentage point in real GDP growth is associated with a 0.9 percentage point growth in SME employment. This implies that to create $1 \%$ of additional SME jobs, an increase in real GDP of $1.1 \%$ is required (European Commission 2015).

Table 3. Growth of Value Added in Manufacturing and Services, 2008 to 2014 (Source: European Commission 2015, taken fromLondon Economics based on data from Eurostat, National Statistical Offices, DIW econ)

\begin{tabular}{c|c|c}
\hline & Manufacturing Sector & Services Sector \\
\hline Micro & $-7,9 \%$ & $7,2 \%$ \\
\hline Small & $-7,6 \%$ & $8,6 \%$ \\
\hline Medium & $0,4 \%$ & $14,2 \%$ \\
\hline SMEs & $3,6 \%$ & $9,5 \%$ \\
\hline Large & $0,1 \%$ & $9,4 \%$ \\
\hline Total Sector & $-3,9 \%$ & $9,4 \%$ \\
\hline
\end{tabular}

As it follows from the Table 3, demand for manufactured goods has been weak in general, thus hurting especially micro and small companies. At the same time demand for services grew substantially and contributed to growth of all kind of SMEs by their size.

In the time period from 2008 to 2014 the contribution of individual sectors to overall EU SME employment gains or losses shows a highly skewed distribution, with a limited number of sectors accounting for the bulk of gains or losses. In the case of net employment creation, four sectors accounted for $52 \%$ of all net employment creation: "Activities of head offices; consultancy", "Services to buildings and landscape activities", "Employment activities", and "Food and beverage service activities". In the case of net employment losses, four sectors accounted for 59\% of net employment destruction: "Construction of buildings", "Specialised construction activities", "Manufacturing of fabricated metal products excluding. machinery and equipment", and "Manufacturing of wearing apparel" (European Commission 2015). Given structure of employment creation and destruction in the EU SME sector shows that knowledge intensive activities are doing better in terms of employment.

EU SMEs in knowledge intensive services increased employment by 9\% from 2008 to 2013. Net employment creation was particularly strong in knowledge intensive services across all three size classes. Knowledge intensive micro firms grew in employment by $9 \%$. Small and medium firms grew by $9 \%$ and $10 \%$ respectively. The less knowledge-intensive service sector, which accounts for almost half of all SME jobs, showed only very modest net 
employment creation of $2 \%$ over this period. The performance pattern of relatively stronger net employment creation in the knowledge-intensive services, compared with the less-intensive services, was repeated in 2014 (European Commission 2015). The specialization of large enterprises on their core activities have significantly contributed to development of knowledge intensive professional outsourcing services provided by SMEs sector in the European Union.

EU SMEs in high-techology reduced their employment by $5 \%$ over the same period of time. The goods-producing industries showed a very different pattern in 2014 relative to the period 2008-13. Only the medium-low tech and low tech industries recorded positive, albeit limited, employment growth in 2014, while employment in high tech industry declined marginally, and remained broadly unchanged in high-medium tech industry. Among small and medium firms, the high-tech sector was the worst performer $(-1 \%)$, while employment in medium-high and medium-low tech firms stagnated in 2014 (European Commission 2015). This tendency can be partially explained by growing labour efficiency and productivity in high-technology industries, but, given its strategical importance, specific policy measures are needed to improve the employment processes in the sector.

European Commission recently launched the "I4MS" initiative (ICT for Manufacturing SMEs) that will help 200 SMEs across Europe, who are either attempting to reduce the risks involved in using advanced technology which is still in its infancy, or are trying to cross the so-called "valley of death" that separates the development of an innovative prototype from a successful product in the market. I4MS is part of the Public Private Partnership 'Factories of the Future' (PPP FoF) launched in November 2008 within the European Economic Recovery Plan to respond to the global economic crisis. This partnership aims at helping EU manufacturing enterprises, in particular SMEs, to adapt to global competitive pressure by improving the technological base of manufacturing across a broad range of sectors (European Commission 2013a). In 2013, the European Commission contributed 77 million euros from its Seventh Framework Programme (FP7) to an innovation initiative for the manufacturing sector aiming at strengthening the competitiveness of European high-tech small and medium size enterprises. This initiative towards information and communications technology (ICT) for manufacturing SMEs - started on July 1, 2013. Through it innovators across value chains in manufacturing and engineering were connected to better profit from newest advances in ICT. For users, that means reducing their risk in being an early adopter of innovative ICT. For suppliers, that means helping to advance innovative prototypes towards a successful product (Lemke 2013). The EU contribution of $€ 77$ million amounts to around $13 \%$ of the total budget of $€ 600$ million of the PPP FoF (European Commission 2013a).

These policy measures launched by European Commission can partly help to declining Europe's high-tech industry. European Commission has recognized technology's importance to Europe's future development and competitiveness of upcoming social challenges, still policy makers' efforts have not done enough to foster a growing high-tech sector.

\section{Conclusions}

Labour economics includes the factors affecting the efficiency of the workers, their deplopment between different industries and occupations, modern labor economics especially deals with the labor force of contemporary industrialized economies. The Economic dimension of employment is mainly the labor market. In general, employment is the result of equilibrium determined by labor market: a working-age population that has been able to carry out activities that can generate income in the form of wages or profits.

Active labour market policies with hiring incentives in European Union seem to be risky as the subsidizing of employees use to have negative effects on employment of those not subsidized. Thus subsidizing should be selective, well-targeted, and not the general approach to unemployment problems in Europe.

Accumulated amount and quality of knowledge by population of industrialized countries coupled with the relatively high level of computer literacy contributed to the revitalization of the business services vendors. Significant role in service sector markets is played by SMEs. Today they demonstrate not only strong sales growth, but also the ability to create and implement innovations, especially in service sector.

The knowledge-intensive business services are the main driving factor of economic development. Development of knowledge-intensive high-tech manufacturing is needed to solve the problems of economic growth. In European countries employment in the service sector is still largely focused on traditional areas of activity. Knowledge-intensive business services that are crucially important for the economic development are only starting to conquer positions in the EU single market.

The increase of employment in non-knowledge-intensive business services SMEs thus promotes strengthening the position of the middle class, but does not act as a guarantor for ensuring high rates of economic growth. Therefore, it is extremely important to develop knowledge-intensive services in order to increase employment in European countries.

Strong policy measures by European Commission are needed to vitalize SME sector in high-technology industries as European Union is losing its competitive position in global markets in particular to USA companies. Public Private Partnership "Factories of the Future" initiative is successful first step to promote European high-tech SMEs, but further funds allocations and other stimulus are still needed. 


\section{References}

Baumol, W. J. 1967. Macroeconomics of unbalanced growth: the anatomy of urban crisis, American Economic Review 57(3): 415426.

Baumol, W. J. 2001. Paradox of the services: exploding costs, persistent demand, in T. Ten Raa, R. Schettkat (Eds.). The growth of service industries - the paradox of exploding costs and persistent demand (Chapter 1). Edward Elgar Publishing Limited. https://doi.org/10.4337/9781781951231.00009

Castells, M. 2007. Communication, power and counter-power in the network society, International Journal of Communication 1: 238-266.

Castells, M. 2009. The rise of the network society. The information age: economy, society, and culture. Vol. 1. $2^{\text {nd }}$ ed. with a new preface. Wiley-Blackwell. https://doi.org/10.1002/9781444319514

Deloitte. 2013. Global Manufacturing Competitiveness Index [online], [cited 10 January 2017]. Available from Internet: https://www2.deloitte.com/global/en/pages/manufacturing/articles/2013-global-manufacturing-competitiveness-index.html

Encyclopaedia Britannica. 2016. Labour Economics [online], [cited 16 December 2016]. Available from Internet: http://www.britannica.com/topic/labour-economics

European Commission. 2010. Communication from the Commission to the European Parliament, the Council, the European Economic and Social Committee and the Committee of the Regions. Brussels, COM (2010) 614. European Commission [online], [cited 16 December 2016]. Available from Internet: http://eur-lex.europa.eu/legal-content/EN/TXT/?uri=CELEX:52010DC0614]

European Commission. 2011. Innovation Union Competitiveness report 2011. Luxembourg: Publications Office of the European Union, 376-377.

European Commission. 2013a. Digital Agenda: European Commission gives $€ 77$ million boost to high-tech manufacturing sector SMEs [online], [cited 17 December 2016]. Available from Internet: http://europa.eu/rapid/press-release_IP-13-533_en.htm

European Commission. 2013b. Innovation Union Competitiveness report 2013 [online], [cited17 December 2016]. Available from Internet: https://ec.europa.eu/research/innovation-union/pdf/competitiveness_report_2013.pdf

European Commission. 2014. Competing in Global Value Chains. EU Industrial Structure Report 2013 [online], [cited 17 December 2016]. Available from Internet: file:///C:/Downloads/EUIS\%202013\%20report\%20-\%20master\%20for\%20print.pdf.

European Commission. 2015. Annual Report on European SMEs 2014/15. SMEs start hiring again. K. Hope (Ed.) [online], [cited 18 December 2016]. Available from Internet: file:///C:/Downloads/annual-report_en\%20(2).pdf

Eurostat. 2015a. Annual detailed enterprise statistics for industry (NACE Rev.2, B-E) [online], [cited 18 December 2016]. Available from Internet: https://data.europa.eu/euodp/en/data/dataset/hVEPsB0XIdBfx9oXmOPg

Eurostat. 2015b. Annual enterprise statistics for special aggregates of activities (NACE Rev.2) [online], [cited 17 December 2016]. Available from Internet: https://data.europa.eu/euodp/en/data/dataset/tKCEWhcKkoRrlBJLjU1quA

Eurostat. 2015c. High growth enterprises (growth by 10\% or more) and related employment by NACE Rev.2 [online], [cited 17 December 2016]. Available from Internet: http://ec.europa.eu/eurostat/web/products-datasets/-/bd_9pm_r2

Eurostat. 2015d. Employment in technology and knowledge-intensive sectors by NUTS 2 regions and sex (from 2008 onwards, NACE Rev. 2) [online], [cited 17 December 2016]. Available from Internet: http://appsso.eurostat.ec.europa.eu/nui/show.do?dataset=htec_emp_reg2\&lang=en

Eurostat. 2015e. Glossary: Knowledge-intensive services (KIS) [online], [cited 17 December 2016]. Available from Internet: http://ec.europa.eu/eurostat/statistics-explained/index.php/Glossary:Knowledge-intensive_services_(KIS)

Eurostat. 2016. Labour productivity per hour worked (ESA2010) [online], [cited 18 December 2016]. Available from Internet: http://ec.europa.eu/eurostat/web/products-datasets/-/tsdec310

International Labour Office. 2013. Perspectives on labour economics for development. S. Cazes, S. Verick (Eds.) [online], [cited 20 December 2016]. Available from Internet: http://www.ilo.org/wcmsp5/groups/public/---dgreports/---dcomm/---publ/documents/publication/wcms_190112.pdf

International Labour Organization. 1993. Resolution concerning the International Classification of Status in Employment (ICSE). Adopted by the Fifteenth International Conference of Labour Statisticians (January 1993) [online], [cited 17 December 2016]. Available from Internet:

http://www.ilo.org/wcmsp5/groups/public/---dgreports/---stat/documents/normativeinstrument/wcms_087562.pdf

International Labour Organization. 2014. Global Employment Trends 2014. Risk of a jobless recovery? [online], [cited 11 January 2017]. Available from Internet:

http://www.ilo.org/wcmsp5/groups/public/---dgreports/---dcomm/---publ/documents/publication/wcms_233953.pdf

Lemke, M. 2013. I4MS to boost competitiveness of SMEs in manufacturing sector. European Commission [online], [cited 11 January 2017]. Available from Internet: https://ec.europa.eu/digital-single-market/en/blog/i4ms-boost-competitiveness-smesmanufacturing-sector

Mavlutova, I.; Olevsky, G.; Lesinskis, K. 2016. Employment prospects for manufacturing and service enterprises in the European Unian, in C. Bratianu, A. Zbuchea, F. Pinzaru, R. Leon, E. Vatamanescu (Eds.). Proceedings of "Strategica", International Academic Conference, Fourth Edition, 20-21 October 2016, Bucharest, Romania, 122-134.

OECD. 2007. Globalization and structural adjustment. Summary report of the study on globalization and innovation in the business services sector [online], [cited 12 January 2017]. Available from Internet: https://www.oecd.org/sti/38619867.pdf

Pierce, J. R.; Schott, P. K. 2012. The surprisingly swift decline of U.S. manufacturing employment. Technical Report. NBER Working Paper 18655. November 2012. 
Mavlutova, I.; Lesinskis, K.; Olevskis, G. 2017. Contemporary role of SMEs in employment in manufacturing and service industries

Rowthorn, R.; Coutts, K. 2004. Commentary: deindustrialisation and the balance of payments in advanced economies, Cambridge Journal of Economics 28(5): 767-790. https://doi.org/10.1093/cje/beh034

Rowthorn, R.; Ramaswamy, R. 1999. Growth, trade, and deindustrialization, International Monetary Fund Staff Papers 46(1): 1841.

Sloman, J.; Hinde, K. 2007. Economics for Business. $4^{\text {th }}$ ed. Harlow: Prentice Hall, Financial Times.

United Nations Industrial Development Organization. 2013. Industrial Development Report 2013. Sustaining employment growth: the role of manufacturing and structural change [online], [cited 17 December 2016]. Available from Internet: https://www.unido.org/fileadmin/user_media/Research_and_Statistics/UNIDO_IDR_2013_main_report.pdf

World Bank. 2013. World development report 2013 [online], [cited 17 December 2016]. Available from Internet: http://siteresources.worldbank.org/EXTNWDR2013/Resources/8258024-1320950747192/82602931322665883147/WDR_2013_Report.pdf 